\title{
Narrativas de viaje y espacialidad en crónicas de la conquista de América. Apuntes comparativos para una discusión ${ }^{1}$
}

\author{
Valeria AÑón \\ Universidad de Buenos Aires \\ Universidad de La Plata \\ Consejo Superior de Investigaciones Científicas y Técnicas, Argentina
}

\begin{abstract}
RESUMEN
Viaje de conquista, relato y mirada imperial articulan buena parte del corpus de crónicas de la conquista de América. En este marco, la renovada atención crítica hacia la tópica, la retórica, la tradición del relato de viaje occidental ha resultado de enorme provecho para iluminar el corpus cronístico, capitalizando además propuestas de inflexiones poscoloniales y decoloniales en torno a la representación y la construcción de conocimiento. No obstante, una mirada más extendida exhibe los límites de estas propuestas, que anclan en crónicas de tradición occidental buena parte de sus afirmaciones. En este trabajo propongo revisar las nuevas propuestas acerca del relato de viaje y las crónicas, a partir de las cuales organizo un abordaje contrastivo entre crónicas de tradición occidental y crónicas mestizas, en torno a tres zonas textuales: la naturaleza, la ciudad y las representaciones cartográficas.
\end{abstract}

Palabras clave: relato de viaje, crónicas, espacialidad, mirada imperial, representación.

Travel Narratives and Spatiality in Chronicles of the American Conquest. Comparative notes

\begin{abstract}
Conquest journeys, travel narratives and imperial eyes gather together Latin American chronicles from the sixteenth and early seventeenth centuries. In the last few decades, critics have revisited this corpus through written traditions such as travel narrative in Occidental Literature and have stressed the importance to take into consideration topics, rhetoric and poetic. However, a wider approach shows what's to be done yet, especially regarding mestizo chronicles. In this article I will focus, firstly, in the main proposals connected to chronicles and travel writing; secondly, on a comparative approach between occidental
\end{abstract}

1 Este trabajo surge de una generosa invitación de Esperanza López Parada a su Seminario Escrituras Virreinales en la UCM. Mi agradecimiento entonces ante la posibilidad de construir este diálogo transocéanico. 
chronicles and mestizo's ones. Finally I provide an overview of the different approaches, by defining three analytical dimensions: nature, urban space, cartographic representations.

Keywords: travel narratives chronicles, spatiality, imperial eye, representation.

SUMARIO: 1. El viaje y su relato. 2. La naturaleza. 3. La ciudad. 4. Representaciones cartográficas.

\section{El viaje y su relato}

"Antes que la estancia sedentaria, el viaje -el derrotero, la exploración, la migración, el éxodo- se halla en el fundamento mismo del mundo amerindio y también en sus metamorfosis. [...] El viaje participa, a veces dichosamente y casi siempre con duelo, de la razón de ser de América." Con esta afirmación, que prologa una breve recopilación de textos sobre imágenes de América, el crítico argentino Jorge Monteleone (1998: 148) articula los orígenes del Nuevo Mundo en relación con el viaje, antes incluso de que el "descubrimiento" o la "conquista" tuvieran lugar. Ocurre que la definición misma de lo americano se halla ligada a los desplazamientos, las migraciones y las fronteras, complejos conceptos que, a comienzos del presente siglo, no dejan de ser revisados por la crítica -aunque, en general, respecto de los viajeros del siglo XIX en adelante, es decir, desde el viaje romántico, y en consonancia con cierta idea del fin del viaje, atravesado por nuevos fenómenos como el turismo (Colombi, 2004: 139).

Lo cierto es que, como práctica y como género, el viaje presenta múltiples proyecciones: estamos ante un término polivalente que remite tanto a una experiencia como a su relato, y que permite pensar cuestiones discursivas, retóricas y pragmáticas. En este marco, y si bien es cierto que el estudio sobre el viaje (y la escritura de viaje) presenta una extensa tradición, las reflexiones críticas en los estudios literarios coloniales en las últimas décadas han permitido reformular también sus implicancias, ampliando el rango de prácticas y escrituras a considerar: los viajes, las migraciones, los desplazamientos efectivos, y también (y de manera central) sus usos metafóricos (el viaje imaginario o la ensoñación), así como algunos tópicos específicos del relato de viaje, que organizan una trama específica: la partida, el itinerario, el encuentro, el retorno... Es por ello que uno de sus principales estudiosos, James Clifford, sostiene que:

El viaje es un término inclusivo que abarca un amplio rango de prácticas, más o menos voluntarias, de dejar la casa para ir a otro lugar. Este desplazamiento tiene el propósito de una ganancia -material, espiritual o científica- e involucra la obtención de un conocimiento o la vivencia de una experiencia (excitante, edificante, placentera, expansiva, de extrañamiento). (1997: 66, cit. en Colombi, 2004) 
El desprendimiento de lo propio, el desplazamiento espacial, la búsqueda de una ganancia, la obtención de una experiencia o un saber y, muy especialmente, su relato (articulado en torno al pacto de lectura del viaje como experiencia efectiva) caracterizan al viaje y permiten pensar las peculiaridades específicas del viaje de conquista de América que, además, se halla en la génesis de la conformación moderna del viaje como género. Esto es así porque, si bien el viaje tiene una larga tradición en Occidente, y una peculiar actualización en el viaje medieval, que instala la mirabilia y da a luz dos de los libros de viaje más importantes de todos los tiempos y más conocidos en el mundo hispánico, El libro de las maravillas de Juan de Mandevilla y los Viajes de Marco Polo (Rodríguez, 2010: 91), la experiencia del "descubrimiento" y conquista de América transforma esa tópica y esa retórica, a partir de la cual el relato de viaje se desprende de su carácter alegórico y de lo maravilloso, y la formalización de su escritura adquiere otras dimensiones, en relación con el discurso legal y la representación del espacio.

De allí que en las aproximaciones al corpus cronístico como relato de viaje tengan especial importancia las nociones de "orientalismo" y "ojo imperial", que tanto han contribuido a la renovación teórica en este ámbito en los últimos treinta años. Muy rápidamente: uno de los hitos lo constituye la propuesta de Edward Said en Orientalismo (1978), quien sostuvo que el discurso de Occidente sobre Oriente fue construido (entre otros dispositivos y disciplinas) por el discurso de los viajeros. La función de este discurso consistió, en buena medida, en construir estereotipos del Otro para asegurar el dominio y el establecimiento de una relación imperial. Tiempo después, y siguiendo la propuesta de Said, Mary Louise Pratt caracteriza el "ojo imperial" que requiere, asimismo, de una compleja "zona de contacto", a la cual define como "espacio de los encuentros coloniales, espacio en que pueblos geográfica e históricamente separados entran en contacto y establecen relaciones duraderas, relaciones que usualmente implican condiciones de coerción, radical e insuperable conflicto" (1997: 26). En torno a este espacio, conflictivo, concebido diacrónicamente, Pratt se plantea la relación viaje-imperio, viaje-expansión de Occidente, viaje y discurso científico, desde Guaman Poma de Ayala hasta Alexander von Humboldt. En la dimensión que nos interesa, estas aproximaciones resultan cruciales porque permiten pensar los viajes de conquista de América y las llamadas "crónicas de Indias" resultantes de estos en torno a la construcción de un discurso orientalista para América, discurso que se verifica desde los textos fundantes del archivo americano (el Diario de Cristóbal Colón, por ejemplo) y que tendrá largas proyecciones en la cultura latinoamericana posterior.

A partir de allí, en las últimas décadas, los estudios coloniales latinoamericanos han asistido a un persistente debate en torno a las crónicas como género y como relato de viaje. A grandes rasgos es posible definir estos aportes en dos dimensiones centrales y complementarias: una que atiende específicamente a aspectos formales y retóricos, y que ancla el relato de viaje en una tradición genérica con poderosas raíces en el universo medieval; otra que se pregunta por la ambigua pertenencia 
genérica del relato de viaje, sus vínculos con procesos imperiales más amplios y con la conformación de una nueva ecúmene, "espacio de confrontación y reconocimiento de otras culturas y de los otros, mecanismo imprescindible para la identificación cultural de lo propio, del nosotros" (Guerin, 1992: 2), y que enfatiza la representación de identidades o subjetividades en ese desplazamiento.

De la primera dimensión quisiera subrayar la discusión del viaje como "motivo" o "tema" y su inflexión autobiográfica, que poco contribuyen a comprender el género $\mathrm{y}$, en cambio, la estricta atención a aspectos formales que en un primer momento definen el relato de viaje como un discurso "narrativo-descriptivo", donde la descripción cumple un rol fundamental (Carrizo Rueda, 1997: 16) e incluso organiza la narración misma en torno a nociones como la de "espectáculo" y a tópicas de la laudibus urbium. A esta flexión descriptiva suelen sumarse al menos tres dimensiones como constitutivas del relato de viaje: la construcción de un itinerario, la organización de una cronología que organiza el relato del desplazamiento, la presencia constante (constitutiva) de la digresión, muchas veces para dar cuenta de la mirabilia -aunque no solamente, como apuntaremos respecto de las crónicas de Indias (López de Mariscal, 2004: 27)-. Desde una perspectiva que articula el horizonte medieval con las crónicas que nos interesan aquí, Jimena Rodríguez retoma y sistematiza estas tipologías, agregando una dimensión crucial: la de la identificación narrador-viajero (personaje), que además pone en jaque el "uso documental" de la literatura de viajes y el funcionamiento mismo de la representación en este marco (2010: 27). Claro que estas aproximaciones no eliden el aspecto contextual, que convocan en particular a partir de las investigaciones de Roger Chartier (2002) y el universo del lector y del autor, en permanente ampliación y transformación en el siglo XVI. De allí que enfaticen también la conformación de un público lector que tiene su génesis en la Edad Media, recibe el impacto de la imprenta y las transformaciones en las condiciones de producción y circulación, y encuentra en los relatos de viajes al Nuevo Mundo un insumo fundamental para alimentar y ampliar la curiosidad y la avidez, soportando a un tiempo la construcción de imaginarios occidentales respecto de lo americano.

De manera complementaria, no excluyente, otros estudios se centran en la dimensión de la colonialidad y la mirada imperial inscripta en el viaje de conquista como resultado del análisis específico de crónicas de Indias. Se inscribe allí la pregunta por las categorías con que los investigadores piensan el género y sus vínculos con otras textualidades contemporáneas; se alude entonces a la importancia de revisar los marcos discursivos y las tipologías textuales así como a la necesidad de atender a las condiciones sociohistóricas y discursivas que "posibilita el ejercicio de una crítica no inmanentista ni impresionista: ubica el relato de viaje en determinadas condiciones de producción y recepción, permite preguntarse por la relación entre la expansión colonialista del siglo XVII y la emergencia de una retórica descriptiva común a este tipo de textos" (Altuna, 2004: 328), retórica que, preciso es subrayarlo, “... responde a una idéntica mirada 
descriptora [vinculada con el cuestionario de las Relaciones geográficas] como consecuencia de una política estatal en el ámbito de una situación colonial" (Altuna, 2002: 32). Retórica e ideología se entrelazan de manera definitiva y permiten pensar otras instancias del viaje particularmente productivas en estas crónicas: la representación de identidades, la instancia del encuentro con el gran señor, el espacio como topos y construcción central en todo relato de viaje (Colombi, 2006: 20). En cualquier caso, incluso esta dimensión crítica respecto del relato de viaje alude en especial a las crónicas de tradición occidental, quizá porque suele concebirse al viaje como "eje estructurador del relato occidental" (López de Mariscal, 2004: 32).

En este contexto, entiendo que, a partir de estas escuetas genealogías entrecruzadas, es posible trazar tres dimensiones para comprender la forma en que el "giro del viaje" impacta en los estudios coloniales, con distinto énfasis ya sea que se trate de investigaciones desde América Latina o sobre América Latina (ese tan agitado debate, aún no zanjado). Postulo que esas dimensiones, concebidas también como topos y que surgen de una perspectiva que articula crónicas de tradición occidental e indígena, son la naturaleza, la ciudad y la cartografía. Las tres se entrecruzan, además, a partir de la articulación entre Imperio, colonialidad y geopolítica del conocimiento, en una compleja trama que los estudios coloniales contribuyen a desanudar, pero en la cual queda aún mucho por hacer, en particular en relación con las crónicas de tradición indígena y las crónicas mestizas (Lienhard, 1983: 105). Para dar cuenta escueta de estas dimensiones, aludiré en especial a un corpus de crónicas novohispanas y andinas, que tienen como eje las conquistas de México y Perú, respectivamente. Por partes, entonces.

\section{La naturaleza}

Ya desde el primer viaje de Cristóbal Colón, estas nuevas tierras fueron definidas por lo abrumador, desmesurado, intrincado de su espacio natural, cuyos hombres -buenos salvajes o caníbales en la mirada colombina- connotaban la medida de la extrañeza de un universo de compleja aprehensión. Para dar cuenta de esta naturaleza indómita, Colón -nutrido en los relatos de viaje medievales- recurre al símil y a la comparación: todo lo nuevo debe tener su correlato en lo conocido; se trata de observar "nuevas tierras con viejos ojos" (Tuninetti, 2001) y de ser capaz de transmitirlas en imágenes que no quiebren de manera abrupta la posición del sujeto ante sí y ante el mundo. En este sentido, el símil, en su movimiento etnocéntrico, resulta tranquilizador; lejos de atentar contra las fronteras de la identidad, las confirma en sus -de todos modos- lábiles certezas. Así, lo exótico se hace familiar: de este modo procedería la mirada también en las cartas de relación de Hernán Cortés y en la Historia verdadera de Bernal Díaz del Castillo, por poner solo dos ejemplos famosos. Pero el Almirante también se encontrará ante lo deslumbrante e inaprensible de una geografía, una flora y una fauna en verdad "diferentísimas de las del nuestro", como afirmará Francisco López de Gómara más de medio siglo 
después en su Historia de la conquista de México (1979: 7). Aquí, el tópico de lo inefable resulta insuficiente; excede la mirada del viajero que alude a lo diverso (siempre en relación con lo propio) y exige una comparación que involucre un juicio de valor. Se acudirá entonces a lo maravilloso y lo exótico, lo mítico y lo demoníaco; la naturaleza americana será objeto de asombro y utopía hasta llegar a afirmar indicios ciertos de la existencia del Paraíso Terrenal en América, como señala Colón en su Tercer Viaje. Las representaciones se organizarán a partir del tópico de la abundancia y su contraparte, el tópico de la carencia, en la mirada del conquistador que percibe el espacio americano en términos de beneficios y riquezas; de allí la insistencia con que el término "oro" estructura el primer diario colombino ${ }^{2}$.

Con múltiples desplazamientos y transformaciones, esta perspectiva acerca de la naturaleza americana constituye una mirada fundante sobre el Nuevo Mundo, que las crónicas novohispanas de tradición occidental se encargarán de refrendar o modificar en el relato de vivencias singulares. La expedición de Hernán Cortés a Tenochtitlan, realizada entre 1519 y 1521, también es -en especial, quizás- un viaje. Como tal, los relatos acerca de ella por parte de sus narradores-protagonistas (Cortés y Bernal Díaz en primer lugar, pero el corpus podría ampliarse hacia las crónicas de Bernardino Vázquez de Tapia y Francisco de Aguilar, entre otros) participan de esta codificación, en las inflexiones del relato medieval y sus transformaciones en el siglo XVI. Claro que no se trata de un viaje naturalista ni bucólico; por el contrario, la mirada lleva inscripta la modulación de la conquista y toda la naturaleza es aprehendida según esta lógica mercantil que organiza cada paso del relato con atención a un objetivo ulterior. En la expedición a Tenochtitlan, el narrador capitán y el narrador soldado se han detenido a ponderar y "saber el secreto" (Cortés, 2010: 146) de extraños fenómenos como el volcán Popocatépetl o a rememorar el frío con que las alturas del centro de México sorprendían a los conquistadores; la geografía, la flora y la fauna mesoamericanas son aprehendidas y representadas de acuerdo con esta ambivalente perspectiva de lo semejante y lo diverso, típica de estos viajeros. En cualquier caso, tanto en la representación del espacio natural como del urbano predomina el símil: todo es semejante a lo español, traducido en nombres y formas conocidas y afines, para un destinatario y un público ávidos de lo exótico, aunque refractarios a lo absolutamente distinto. Por eso, las miradas de estos narradores mensuran, cuentan, inventarían, ordenan y segmentan:

${ }^{2}$ Estas aproximaciones han sido planteadas por diversos especialistas, en particular por Antonello Gerbi en La naturaleza de las Indias Nuevas (1975), El Viejo Mundo y el Nuevo de John H. Elliot (2000), La naturaleza como problema histórico de David Arnold (2001) y Ottmar Ette, Literatura en movimiento (2008), por nombrar solo los más destacados. Analicé de manera pormenorizada las distintas instancias del viaje en el prólogo a Diario, cartas y relaciones. Antología esencial de Cristóbal Colón (2012: 46). 
aprehenden en una lógica propia, antitética, un referente que -como todo objeto, en cierta medida- se muestra elusivo o diverso.

Esta operación para narrar el espacio urbano y la naturaleza mesoamericana exhibe otras complejidades en las llamadas "crónicas mestizas" novohispanas, entre las que destaco la Historia de Tlaxcala de Diego Muñoz Camargo y la Historia de la nación chichimeca de Fernando de Alva Ixtlilxóchitl; quizá por eso también algunas ciudades y ciertas referencias geográficas que tanto asombran al conquistador reciben en estas crónicas un espacio textual algo acotado. Ya no se trata de narrar lo desconocido o lo ajeno: ahora se está ante la familiaridad de una memoria que es asumida como propia -aunque también contenga infranqueables distancias-, de una lengua en la que aún palpitan concepciones autóctonas del espacio, donde a lo urbano y natural se suma lo cosmogónico y lo mítico: de allí que, por ejemplo, numerosas representaciones espaciales indígenas incluyan en una misma cartografía lo humano y lo divino, en yuxtapuesta contigüidad. Si la conquista y la derrota atenazan estas memorias en la censura, el silencio y el trauma, sin embargo no llega a quebrar por completo el vínculo con el espacio propio. Con estos complejos materiales construyen sus representaciones las crónicas mestizas; a ellos se deben también algunos silencios, ciertas focalizaciones, jugosas puestas en relieve de espacios sociales, alianzas, diferencias territoriales, enfrentamientos y negociaciones que constituyen la memoria rota, herida, pero aún palpitante de cada comunidad.

En este juego entre el acercamiento y la distancia, entre la diversidad y el símil, entre la apropiación, el lamento y el asombro se constituyen las representaciones de la naturaleza en torno a la conquista de México y, en especial, en el viaje del fracaso que se narra al final de ella: la expedición a las Hibueras (1524-1526). En efecto: una vez superadas las zonas textuales que narran la conquista de México, buena parte de ellas -menos las historias tlaxcaltecas- se detiene a narrar otro desplazamiento, el viaje a la actual Honduras que Hernán Cortés encabeza dos años y medio después de la caída de Tenochtitlan. Espacio de la extrañeza, donde lo urbano retrocede y la naturaleza irrumpe, este viaje constituye la contracara de la expedición de victoriosa conquista. Como un aleph de múltiples metáforas, las Hibueras configuran el locus del deseo y de la traición; la oportunidad de la conquista y la aventura contra la ociosidad en México; el punto de convergencia y desajuste entre las representaciones occidentales y las autóctonas; lo inconmensurable e imposible; la crueldad, la injusticia y la infamia -como no cesará de reiterar Fernando de Alva Ixtlilxóchitl ante la muerte de Cuauhtémoc, tlatoani mexica prisionero-; el viaje del fracaso y de la pérdida. Se trata, en verdad, de la configuración textual de un espacio extraño, articulado en torno a la descripción de un derrotero que reta las concepciones del Otro y del Yo tal como se han venido desplegando a lo largo del relato de la expedición a Tenochtitlan; en la representación de una naturaleza americana desbordada, oscura y amenazante. Codificada de acuerdo con las características del relato de viajes tanto en la Quinta 
carta de relación de Hernán Cortés como en la Historia verdadera de Bernal Díaz (Rodríguez, 2010: 193), articulada también de acuerdo con el orden específico y elíptico del discurso histórico letrado en la Historia de la conquista de México y el Compendio histórico del Reino de Texcoco (Añón, 2012: 289), la expedición a las Hibueras pone de relieve los cambios en la subjetividad que esta experiencia y su representación inscriben en cada crónica, en relación especular y antitética con el relato de la expedición a Tenochtitlan ${ }^{3}$.

Estamos así ante dos dimensiones fundamentales: espacio y subjetividad, por un lado; representación y antítesis, por otro. Ambas se reiteran en las representaciones de ciudades, dimensión central en los estudios literarios coloniales en general y en torno a los relatos respecto de la conquista de México en particular.

\section{La ciudad}

En las últimas décadas, el vínculo entre espacialidad, desplazamiento, representación y viaje han sido eje de abordajes que exceden los estudios acerca de lo urbano para ampliar el uso metafórico del concepto. Dichas modulaciones de la representación tienen un correlato factual específico en la medida en que, a partir del descubrimiento y la conquista de América, la ciudad ha sido foco de la legalidad de dicha conquista, locus fundamental de establecimiento y avanzada, representación del poder imperial y sus deseos (Romero, 2001: 45). Lecturas, imágenes e imaginarios confluyeron proyectando sobre territorio americano comunidades ideales vinculadas al humanismo, ciudades edénicas o inspiradas por un espíritu milenarista. Ciudades originarias, ciudades asiáticas, ciudades míticas; concepciones medievales y renacentistas del espacio urbano confluyeron en el asedio, la conquista y el trazado. En una dimensión complementaria, el tramado urbano discursivo organiza cartografias imaginarias, itinerarios articulados a partir del deseo o la invención, espacios urbanos fantasmáticos que expanden y cuestionan las posibilidades mismas de la representación. Las primeras representaciones del espacio urbano americano pueden remitirse a los primeros textos colombinos (1492-1493), donde se enfatiza todo lo que de fundacional (e imperial) tiene el gesto de marcar como tabla rasa un territorio al que se inventa e imagina desnudo, virgen. En este contexto, inscripción textual del espacio, del Otro (buen salvaje o caníbal), y sobreimpresión de un ideal propio de asentamiento (el Fuerte de Navidad) constituyen los gestos inaugurales de la violencia de la representación.

\footnotetext{
${ }^{3}$ Respecto de las expediciones fracasadas y el relato de viaje, aunque para viajeros a la Patagonia y la Amazonía, por un lado, y viajes al Río de La Plata, por el otro, se destacan las propuestas de María Jesús Benites, quien define una "narrativa del desamparo" (2014: 189) y de Loreley El Jaber, que despliega y analiza la "escritura del desencanto" (2011: 22).
} 
Claro que si estas representaciones fundan un tópico y un estereotipo de América, es el viaje de conquista hacia los fabulosos territorios mexicanos que narran las Cartas de relación del capitán extremeño Hernán Cortés (en especial la Segunda y la Tercera), el que configurará un modelo de conquista y de relato en torno al cual $-\mathrm{y}$ en polémica con el cual- se organiza buena parte de la conquista posterior del continente (y de sus relatos), tanto en las expediciones exitosas como en las fracasadas. Recordemos, en primera instancia, que las cartas de relación constituyen textos fundamentales y fundantes del archivo americano, primera imagen occidental sobre el centro de México, y que alcanzan enorme difusión ya desde el momento de su primera circulación por Europa (la primera edición en castellano fue llevada a cabo por Jacobo Cronenberg en Sevilla en 1522), en consonancia con la avidez de un público lector subyugado por el relato de viaje. Asimismo, se trata de textos que articulan, de manera paradigmática, relato de viaje y discurso legal, viaje de conquista y legitimación de esa conquista, tanto más necesaria en la medida en que surge de una desobediencia abierta a las órdenes del representante del rey, Diego Velázquez. Este entramado configura un lugar de enunciación diferencial, que hará de la representación-apropiación del otro americano (y de su espacio) razón de ser del desplazamiento y del discurso. Vayamos, entonces, al comienzo:

Muy alto y Poderoso y Muy Católico Príncipe, Invictísimo Emperador y Señor Nuestro: En una nao que de esta Nueva España de Vuestra Sacra Majestad despaché a diez y seis días de julio del año de quinientos y diez y nueve, envié a Vuestra Alteza muy larga y particular relación de las cosas hasta aquella sazón, después que yo a ella vine, en ella sucedidas. [...] Y después acá, por no haber oportunidad, ansí por falta de navíos y estar yo ocupado en la conquista y pacificación de esta tierra, como por no haber sabido de la dicha nao y procuradores, no he tornado a relatar a Vuestra Majestad lo que después se ha hecho; de que Dios sabe la pena que he tenido. Porque he deseado que Vuestra Alteza supiese las cosas de esta tierra, que son tantas y tales que, como ya en la otra relación escribí se puede intitular de nuevo emperador della y con título y no menos mérito que el de Alemaña, que por la gracia de Dios Vuestra Sacra Majestad posee. Y porque querer de todas las cosas de estas partes y nuevos reinos de Vuestra Alteza decir todas las particularidades y cosas que en ellas hay y decir se debían, sería casi proceder a infinito. (Cortés, 2010: 91-92)

A partir de esta enunciación inaugural, que se solaza, como dicta la retórica, en la captatio benevolentia que habilita la escritura dirigida a la autoridad (la adjetivación hiperbólica, el uso de vocativos específicos, los tópicos de lo inefable y lo inenarrable), se configura el discurso como conquista y como espacio de la polémica. En ese derrotero se articula una imagen de conquistador/narrador que define aliados y enemigos tanto en el universo indígena como en el español, complejizando la construcción del yo y del otro inaugurada con la dicotomía 
colombina. Por otro lado, el párrafo constituye el "comienzo" (Said, 1985: 3) de una textualidad organizada en el cruce de tradiciones discursivas y convergentes (el discurso legal, el discurso histórico, el discurso bélico, el discurso bíblico y escatológico, las novelas de caballerías) en el cual el relato de viaje, como tópica y como retórica, jugará un rol central en la construcción de una autoridad enunciativa y en la representación del encuentro. A partir de allí se articula una mirada imperial que cuantifica, ya desde el inicio, lo que se conquistará luego, y que exaspera el peso descriptivo de toda relación, al tiempo que pone en escena la inscripción del conocimiento sobre el otro como forma de apropiación. Se trata de brindar información e inscribir nuevas epistemologías basadas en la experiencia de una primera persona testimoniante y protagonista, en otro giro del pacto de lectura implícito a todo viaje: el que escribe es el que viaja (Colombi, 2006: 14).

La primera persona enunciadora se conforma así en la capacidad de transmitir esa experiencia, articulándola en una trama que le dé sentido. Es en relación con esa trama que ingresa de manera central la estructura y la organización textual que habilita la tradición del relato de viaje. De allí que podamos afirmar que la tópica, la retórica y la forma del relato de viaje son directamente funcionales a la trama polémica que sostiene la legitimación del enunciador-conquistador, desde las Cartas de relación en adelante. Recordemos que, en tanto estructura general del texto o bien como relato enmarcado en un texto mayor, todo relato de viaje se articula en función de un itinerario (definido mediante coordenadas temporoespaciales), con un narrador-protagonista que, como ya señalamos, erige su autoridad a partir de una retórica de la experiencia, el esfuerzo y la fatiga. En líneas más generales y teniendo en cuenta las características mencionadas, la trama de las Cartas de Relación se organiza narrando un desplazamiento espacial, desde Veracruz hasta Tenochtitlan, por medio de la inscripción de topónimos, accidentes geográficos y distancias recorridas, donde los emplazamientos urbanos constituyen jalones en un itinerario que se presenta (se quiere) rectilíneo, certero, veraz. Transitar, nombrar, fundar (Villa Rica), poblar: el narrador inscribe gestos fundamentales en toda crónica de conquista que subrayan la mirada y la actitud imperial.

En este itinerario urbano que tiene en el recorrido por Tenochtitlan su clímax y su momento de organizado esplendor se erigen dos instancias espaciales cuya descripción da cuenta de cómo la mirada occidental/imperial sobreimprime, en primer lugar de manera simbólica, un "orden y concierto" ajenos: el mercado y el templo. Por razones de espacio, me centraré aquí en el primero:

Tiene esta ciudad muchas plazas donde hay continuo mercado y trato de comprar y vender. Tiene otra plaza tan grande como dos veces la ciudad de Salamanca toda cercada de portales alrededor donde hay cotidianamente arriba de sesenta mil ánimas comprando y vendiendo; donde hay todos los géneros de mercadurías que en todas las tierras se hallan ansí de mantenimientos como de vituallas, joyas de oro 
y de plata, de plomo, de latón, de cobre, destaño, de piedras, de huesos, de conchas, de caracoles y de plumas. Véndese cal, piedra labrada y por labrar, adobes, ladrillos, madera labrada y por labrar de diversas maneras. Hay calle de caza donde venden todos los linajes de aves que hay en la tierra, así como gallinas, perdices, codornices, lavancos, dorales, cerzatas, tórtolas, palomas, pajaritos en cañuela, papagayos, buharros, águilas, halcones, gavilanes y cernícalos. Y de algunas destas aves de rapiña venden los cueros con su pluma y cabezas y pico y uñas. Venden conejos, liebres, venados, y perros pequeños, que crían para comer, castrados. Hay calle de herbolarios, donde hay todas las raíces y hierbas medicinales que en la tierra se hallan. [...] Finalmente, que en los dichos mercados se venden todas cuantas cosas se hallan en toda la tierra, que demás de las que he dicho son tantas y de tantas calidades que por la prolijidad y por no me ocurrir tantas a la memoria, y aun por no saber poner los nombres no las expreso. (Cortés, 2010: 184-185)

No puedo detenerme en el análisis pormenorizado de esta caracterización; sí quisiera señalar que, en un recurso descriptivo característico, el mercado se actualiza por medio de una iterativa e hiperbólica enumeración, que describe, por analogía, la multiplicidad de bienes. Este recurso (y esta escena), que vinculan el texto con los relatos de viaje, son retomados y ampliados por otros cronistas de esta conquista, como Francisco López de Gómara y Bernal Díaz del Castillo. En todas las descripciones se organiza el espacio en relación con dos tópicos: la multiplicidad y heterogeneidad fabulosas de objetos y seres y, en paradójica concomitancia, el orden y concierto que rige el intercambio (Añón, 2012: 256). A ello se suma el fundamental recurso de la evidentia (que implica "poner todo delante de los ojos del lector") que subyace a la descripción analítica, la amplificatio y la enumeración hiperbólica de todo lo que hay y se vende en el mercado de Tlatelolco, configurando entonces un catálogo -al que, justo es decirlo, toda descripción tiende- que inventaría lo que conquistará. Se configura, asimismo, la función persuasiva de la descripción: la maravilla hiperbólica del mercado busca convencer y asombrar al destinatario real (y a un público más amplio), preparando la apropiación que, hacia el final del texto, se cierra con la nominación, cuando el capitán llama a este territorio "Nueva España” (Añón, 2010: 267, n. 277).

Por otro lado y en términos de trama, el mercado se contrapone al espacio del Templo Mayor de Tenochtitlan, descripto de inmediato en el texto, a partir de una serie de modelos binarios para la aprehensión del espacio Otro: adentro/afuera, arriba/abajo; lo semejante/ lo antitético. Por contigüidad diegética, la escena se construye en un frágil equilibrio entre la majestuosidad de esta civilización y la destrucción de toda conquista; de allí la necesidad de su articulación con el templo, cuyas características - expresión de una religión presentada como demoníaca e infernal- sustentan el asedio a Tenochtitlan. Por otro lado, aterrado por el olor a sangre y a muerte, por las huellas de los sacrificios humanos y las idolatrías, el narrador escenifica los límites de su mirada, donde entra a tallar otra dimensión fundamental de su autoridad enunciativo/conquistadora: la evangelización y el 
providencialismo (Añón, 2012: 255). Esta contraposición fundamental exhibe las marcas de las posibilidades y límites de una mirada imperial, que serán modelo descriptor para toda crónica de conquista posterior.

Dando cuenta de continuidades y transformaciones, variadas crónicas de tradición occidental (López de Gómara, 1552; Bernal Díaz, 1584) e indígena (el Inca Garcilaso de la Vega, 1609; Guaman Poma de Ayala, 1613-1615; la Historia general de fray Bernardino de Sahagún, 1580), presentan dos ciudades paradigmáticas como núcleo, vinculadas a las expediciones de conquista: MéxicoTenochtitlan y Cuzco. En estas crónicas, organizadas entre la retórica descriptiva y la experiencia, entre las ciudades míticas y la majestuosidad de los espacios americanos, se erigen distintos tipos de urbes con funciones textuales diversas. De allí que las grandes ciudades indígenas (Tenochtitlan y Cuzco) funcionen como organizadoras de la diégesis de cada crónica, respondiendo a una retórica descriptiva que articula el universo topológico de la descriptio civitatis, la forma narrativa del relato de viaje y las modulaciones de la mirada imperial (en el caso de la tradición occidental) o bien melancolía, nostalgia, errancia y reclamo (en el caso de la tradición indígena). De manera escueta, solo quisiera subrayar la potencia diegética, en términos de organización y definición de la trama, que las ciudades presentan en crónicas de tradición occidental e indígena, porque es este funcionamiento representacional el que me interesa retomar para abordar las crónicas mestizas, habitualmente interrogadas, en cambio, en términos de verdad, resistencia y etnicidad (Añón, 2013: 3).

\section{Las representaciones cartográficas}

Pero este corpus permite dar un giro más a las investigaciones literarias y culturales, en la medida en que presenta en lugar de enorme relevancia representaciones cartográficas espaciales, de las cuales el Mapa de Nuremberg (también conocido como Mapa de Cortés porque acompaña la edición latina de la Segunda y Tercera carta de relación de 1523) es prototípico ejemplo. Este es, quizás, uno de los textos cartográficos más analizados y discutidos: José Rabasa (1993), Walter Mignolo (1995), Bárbara Mundy (2000), Ricardo Padrón (2004), Carlos Jáuregui (2008) y, más recientemente, Esperanza López Parada (2013) le otorgan un lugar preponderante en sus análisis, ya sea enfatizando la tradición occidental o la indígena. 


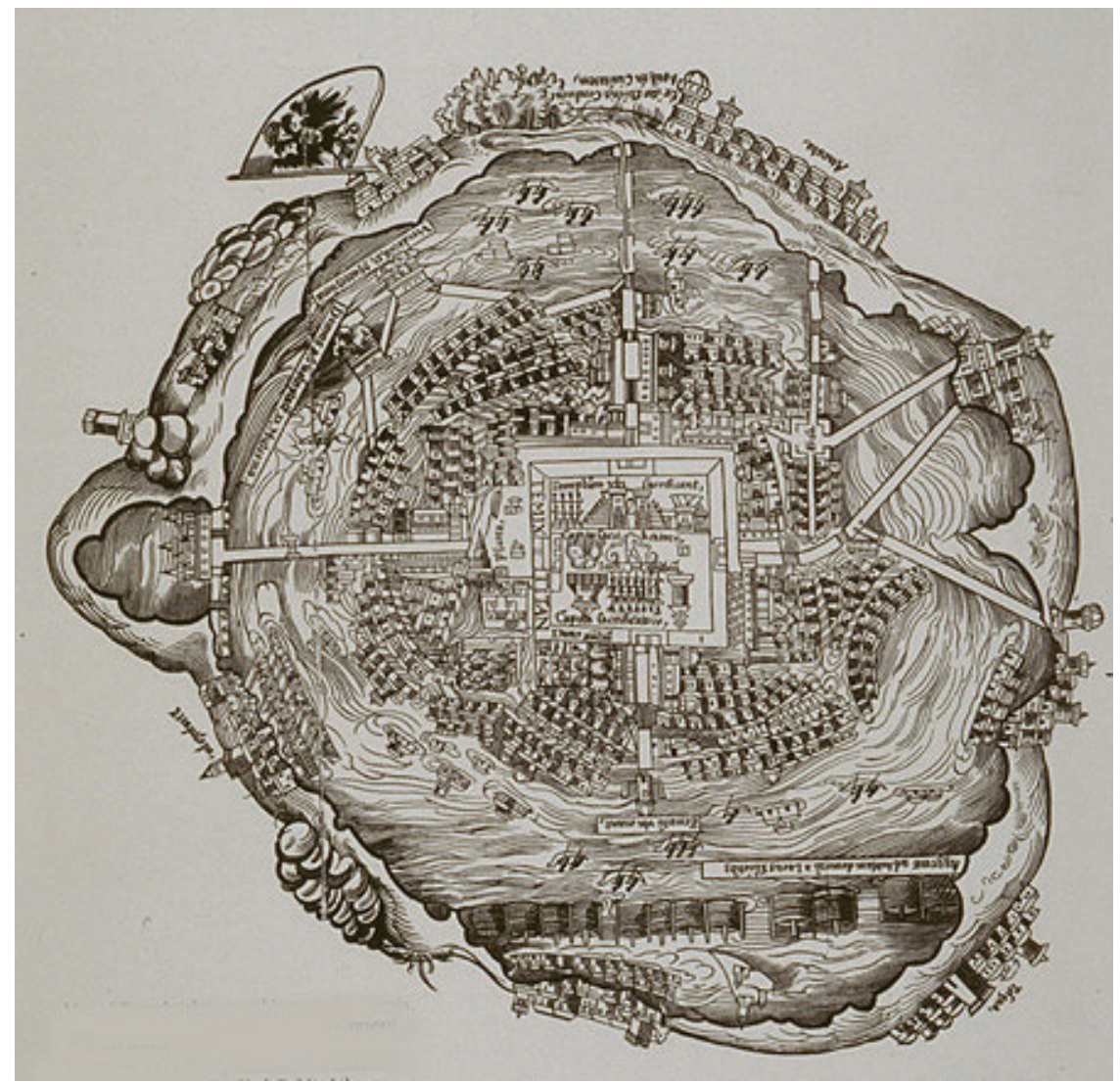

Poderosa imagen de gran belleza, su híbrida representación reúne la mirada exótica con lo anatematizante del sacrificio, la importancia del centro ceremonial, la referencia a los dos templos (que Mundy lee en clave indígena, 2000: 18), la atracción de la circularidad y cierto orden (de raíz humanista), la persistencia de una gama cromática donde el azul tiene un rol fundamental, remitiendo asimismo al elemento acuático tan poderoso en la cosmogonía nahua y en otras representaciones de México-Tenochtitlan, como el frontispicio del Códice Mendoza. En cualquier caso, este entrecruzamiento deja pocas dudas respecto de los elementos que perviven a lo largo del tiempo, como lo demuestra López Parada (2013: 162): el elemento autóctono pierde fuerza, y prevalece la representación occidental cartográfica del espacio, puntapié inicial de la "colonización del imaginario" a la que se refirió Serge Gruzinski (1995: 33). Pero este mapa nos permite, además, sistematizar muchas de las operaciones de representación del espacio de tradición occidental: el relato de viaje y su matriz descriptiva; la mirada imperial que se solaza en el inventario de lo que luego conquistará (en el mercado de Tlatelolco, por ejemplo); la descriptio civitatis y la novela de caballerías, que articulan las primeras 
imágenes, encantadas -entre el tópico de lo maravilloso y el de lo inefable- de Tenochtitlan, en especial en la Historia verdadera; la justificación de la conquista y de las justas causas de la guerra, en una descripción del espacio que es descripción del otro salvaje/idólatra y, por tanto, legítimamente conquistable. Matriz colonialimperial y representación cartográfica del espacio se erigen, de manera casi transparente para exhibir los vericuetos de la colonialidad del poder.

En cualquier caso, la representación cartográfica no es privativa de las crónicas de tradición occidental, sino que ocupa un lugar fundamental en las crónicas mestizas, entre las cuales se destacan la Nueva corónica y buen gobierno de Felipe Guaman Poma de Ayala, analizada por Rolena Adorno (2011: 74), y los mapas de las Relaciones Geográficas y los Títulos Primordiales, abordadas por Bárbara Mundy (2011: 56). Ambas son excelentes ejemplos de los dos mecanismos fundamentales de construcción de la representación en estas crónicas: las tácticas (De Certeau, 2000), los usos del pasado (Hartog, 2007). Retomando elementos de la tradición cartográfica occidental (el Mapamundi de Guaman Poma) o de la tradición legal medieval (los títulos primordiales) estas representaciones exhiben la forma en que las élites indígenas supervivientes reformularon las herramientas legales y simbólicas del conquistador, con el objeto de sostener una salida negociada que les permitiera mantener privilegios o sortear, frente al rey si fuera necesario, la rapiña de los encomenderos. En esta lógica se inscribe, por ejemplo, la Descripción de la cibdad y provincia de Tlaxcala de los principales tlaxcaltecas, redactada por Diego Muñoz Camargo (hipotexto de la Historia de Tlaxcala) y, en rigor de verdad, todo ordenamiento textual que responda a la minuta de la Instrucción y Memoria de la Corona Española (desde 1575 en adelante), utilizada e interpolada por las voces autóctonas, como han analizado, entre otros, Walter D. Mignolo (1987: 451), Serge Gruzinski (1995: 77), Elena Altuna (2009: 21).

Mis aproximaciones a estas crónicas retoman estas tradiciones pero intentan ir un paso más allá, interrogándome, en buena medida, respecto de los usos del espacio en las crónicas mestizas, en un corpus comparativo novohispano y andino. La tesis es que, a diferencia de lo que ocurre con las crónicas de tradición occidental, y en consonancia con las operaciones de negociación y supervivencia de Descripciones, Informes, Probanzas y Títulos producidos por las comunidades autóctonas, el espacio no adquiere un peso descriptivo-inventarial sino, por el contrario, un funcionamiento dinámico, mítico-identitario. Es en torno a las ciudades centrales (Tenochtitlan, Tlatelolco, Tlaxcala, Cholula, Cuzco), a su historia y linaje, al derrotero y el emplazamiento, a la genealogía onomástica y a sus principales gobernantes que se articula la historia y la identidad de cada comunidad. Es en torno a estas ciudades enfrentadas, enemigas, que se articula también la polémica textual, enfrentamiento que llega, muchas veces, a plantear divergencias en torno a la temporalidad misma, al calendario y sus múltiples representaciones cosmogónicas. Tiempo, espacio y cosmogonía se hallan así entrelazados; aunque buena parte de estos sentidos se pierde en las crónicas mestizas, adquieren no 
obstante una dinámica de profundo interés en la medida en que exhiben las posibilidades de la negociación y la supervivencia a partir de la representación.

Propongo entonces volver sobre la trama discursiva-escrituraria de las crónicas mestizas, a las que estas le han confiado buena parte de su significado y de sus posibilidades de legibilidad, como se ve en especial en los citados textos del Inca Garcilaso y de Fernando de Alva Ixtlilxóchitl, por ejemplo. En ellas, la representación de las ciudades funciona en torno a tres dimensiones: la trama de cada crónica; la genealogía de la ciudad (su nombre, su linaje); el centro ceremonial, el palacio y la ruina (Añón, 2013). No puedo desplegar aquí ejemplos de cada una de estas dimensiones; brevemente apuntaré que cada crónica se organiza en torno a una ciudad-centro, estrechamente vinculada con un principal a cuyo linaje pertenece la versión que en ella se ofrezca: Nezahualcóyotl y luego Ixtlilxóchitl en la Historia de la nación chichimeca, Manco Cápac en los Comentarios reales; Cuauhtémoc y Tenochtitlan en los testimonios tlatelolcas de los informantes de Sahagún. Metonimia y acumulación definen así el funcionamiento textual de las ciudades, a diferencia de la desagregación descriptiva, la enumeración imperialista, la segmentación analógica y acumulativa de las textualidades de tradición occidental.

En torno a ellas se configuran tramas de disímil "dibujo": cierta linealidad en la Historia de la nación chichimeca, circularidad y expansión en los Comentarios reales; en ambos casos con un eje central-urbano que mantiene el rumbo. En tanto, el peso simbólico y metafórico está dado por el despliegue del nombre de la ciudad, proceso que nunca es ocioso sino que remite a poderosas matrices de configuración identitaria donde viaje-desplazamiento y migración, asentamiento, conformación de linajes y entretejido de la historia de la comunidad se reúnen para dar sentido a una identidad presente en constante transformación en las sociedades coloniales. La tercera dimensión, fundamental, se vincula con la representación de los "palacios", enaltecidos espacios del pasado, ruinas del presente. Más allá de las pormenorizadas, hiperbólicas y acumulativas descripciones, su funcionamiento singular es metafórico puesto que operan articulando sobre el eje espacial la dimensión temporal: pasado de gloria versus presente de ruina y destrucción. Este será el espacio textual de la elegía y el lamento, también de la crítica abierta al accionar del conquistador (algo que pocas crónicas mestizas se permiten en otros ámbitos). Será asimismo el espacio del pleno funcionamiento de la metáfora como denuncia de la desacralización a la que el conquistador somete el espacio autóctono. Estos ejemplos exhiben otros usos del espacio y del relato de viaje, cuya complejidad entrelazada entre tradiciones occidentales e indígenas constituye el corpus literario latinoamericano.

Entonces, si "para asegurar la tensión necesaria al relato de viaje hace falta la posición específica del colonizador: curioso por conocer al otro, y seguro de su propia superioridad" como afirma Tzvetan Todorov (1993), es la lectura crítica la que debe descolonizar estas actitudes textuales, remedando la curiosidad y la 
tensión para leer, en la retórica, argumentos y usos. Ello permitirá también desnaturalizar imágenes de América que las crónicas de la conquista de tradición occidental han fundado y desplegado a partir de la retórica del viaje, y que persisten, de manera problemática, compleja y sutil, en la cultura y la literatura iberoamericanas contemporáneas. Esa es la apuesta de la lectura comparativa a la que estos breves apuntes buscan contribuir.

\section{BIBLIOGRAFÍA}

ADORNO, Rolena.

2011 “Andean Empire", en Jordana Dym and Karl Offen (eds.), Mapping Latin America. A Cartographic Reader. Chicago: Chicago UP, pp. 74-78.

ALtunA, Elena.

2002 El discurso colonialista de los caminantes. Siglos XVI-XVIII. Ann Harbor, Michigan: Centro de Estudios Literarios "Antonio Cornejo Polar" y Latinoamericana Editores.

2004 "Relaciones de viajes y viajeros coloniales por las Américas", en Revista de Crítica Literaria Latinoamericana, núm. XXX-60, Lima-Hannover, 2do. Semestre, pp. 1-19.

2009 Retórica del desagravio. Estudios de cultura colonial peruana. Salta: CEPIHA.

ALVA IXTLILXÓCHITL, Fernando de.

1997 Obras históricas. México: Instituto Mexiquense de Cultura, Instituto de Investigaciones Históricas de UNAM.

AÑón, Valeria.

2013 "De México a Cuzco: nostalgia, memoria y usos del pasado en crónicas de tradición indígena", Vanderbilt e-Journal of LusoHispanic Studies, vol. 9, 2013, pp. 1-15.

2012 La Palabra despierta. Tramas de la identidad y usos del pasado en crónicas de la conquista de México. Buenos Aires: Corregidor.

2010 "Prólogo" a Hernán Cortés, Segunda carta de relación y otros textos. Buenos Aires: Corregidor.

ARNOLD, David.

2000 La naturaleza como problema histórico. El medio, la cultura y la expansión de Europa. México: FCE.

BENITES, María Jesús.

2014 "Vigilias, fatigas y peregrinaciones': viaje, relato y desamparo en los confines del imperio", en Revista Telar, núm. 11-12, pp. 80-97. 
CARRIZO RUEDA, Sofía.

1997 Poética del relato de viajes. Kassel: Reichenberger. COLOMBI, Beatriz.

2004 Viaje intelectual. Migraciones y desplazamientos en América Latina (1880-1915). Rosario: Beatriz Viterbo.

2006 "El viaje y su relato", Latinoamérica, México, UNAM-CCYDEL, núm. 43, pp. 11-23.

Colón, Cristóbal.

2012 Diario, cartas y relaciones. Antología esencial. Buenos Aires: Corregidor.

CORTÉs, Hernán.

2010 Segunda carta de relación y otros textos. Buenos Aires: Corregidor. CHARTIER, Roger.

1989 El mundo como representación, Barcelona: Gedisa.

De Certeau, Michel.

2000 La invención de lo cotidiano. 1. Artes de hacer. México: Universidad Iberoamericana.

DÍAZ DEL CASTILlO, Bernal.

2005 Historia verdadera de la conquista de la Nueva España (Manuscrito Guatemala). México: El Colegio de México, Universidad Nacional Autónoma de México, Servicio Alemán de Intercambio Académico, Agencia Española de Cooperación Internacional.

ELLIOTT, John H.

2000 El Viejo Mundo y el Nuevo. Madrid: Alianza.

ETTE, Ottmar.

2008 Literatura en movimiento. Espacio y dinámica de una literatura transgresora de fronteras entre Europa y América. Madrid: CSIC.

EL JABER, Loreley.

2011 Un país malsano. Rosario: Beatriz Viterbo.

GARCILASO DE LA VEGA, Inca.

1945 Comentarios Reales. Buenos Aires: Emecé.

GERBI, Antonello.

1975 La naturaleza de las Indias Nuevas. De Cristóbal Colón a Gonzalo Fernández de Oviedo. México: FCE.

GuAman Poma DE AYAla, Felipe.

1984 Nueva corónica y buen gobierno. México: Siglo XXI.

GUERIN, Miguel Alberto.

1992 "El relato de viaje americano y la redefinición sociocultural de la ecumene europea", en Dispositio, núm. XVII-42, pp. 1-19.

GRUZINSKI, Serge.

1995 La colonización de lo imaginario. México: FCE. 
HARTOG, Francois.

2007 Regímenes de historicidad. México: Universidad Iberoamericana. JÁUREGUI, Carlos.

2008 Canibalia. Canibalismo, calibanismo, antropofagia cultural y consumo en América Latina. Ensayos de Teoría Cultural. MadridFrankfurt: Iberoamericana-Vervuert.

LIENHARD, Martin.

1983 "La crónica mestiza en México y el Perú hasta 1620: apuntes para su estudio histórico-literario", en Revista de Crítica Literaria Latinoamericana, núm. IX-17, Lima, 1er semestre, pp. 105-115.

LÓPEZ DE GÓMARA, Francisco.

1979 Historia de la conquista de México. Caracas: Ayacucho.

LÓPEZ DE MARISCAL, Blanca.

2004 Relatos y relaciones de viaje al Nuevo Mundo en el siglo XVI. Madrid: Ediciones Polifemo y Tecnológico de Monterrey.

LÓPEZ PARADA, Esperanza.

2013 "La cartografía como relato: intervenir los mapas, narrar las ciudades", en Revista Orbis Tertius, núm. XVII (19), pp. 158-186.

MigNOLO, Walter D.

1987 "El mandato y la ofrenda. La Descripción de la Ciudad y Provincia de Tlaxcala de Diego Muñoz Camargo y las relaciones de Indias", en Nueva Revista de Filología Hispánica, núm. 35 (2), pp. 451-484.

1995 The Darker Side of the Renaissance. Literacy, Territoriality and Colonization. Ann Arbor: University of Michigan Press.

MONTELEONE, Jorge.

1998 El relato de viaje. De Sarmiento a Umberto Eco. Buenos Aires: El Ateneo.

MUNDY, Bárbara.

2000 The Mapping of New Spain. Indigenous Cartography an the Maps of the Relaciones Geográficas. Chicago: Chicago UP.

MUÑOZ CAMARGO, Diego.

1998 Historia de Tlaxcala. Tlaxcala: Gobierno del Estado de Tlaxcala.

1982 Descripción de la ciudad y provincia de Tlaxcala de las Indias y del Mar Océano para el buen gobierno y ennoblecimiento dellas. México: UNAM-IIH.

PADRÓN, Ricardo.

2004 The Spacious World. Cartography, Literature and Empire in Early Modern Spain. Chicago: Chicago UP.

PRATT, Mary Louise.

1997 Ojos imperiales. Bernal: UNQUI.

RABASA, José.

1993 Inventing America. Norman: Oklahoma UP. 
RODRÍGUEZ, Jimena.

2010 Conexiones transatlánticas. México: El Colegio de México.

ROMERO, José Luis.

2001 Latinoamérica: las ciudades y las ideas. Buenos Aires: Siglo XXI. SAHAGÚN, fray Bernardino de.

1989 Historia general de las cosas de la Nueva España. México: CONACULTA-Alianza.

SAID, Edward.

1978 Orientalism. Londres: Penguin.

1985 Beginnings. Intention \& Method. Nueva York: Columbia UP.

TODOROV, Tzvetan.

1993 "El viaje y su relato", en Las morales de la historia. Barcelona: Paidós.

TUNINETTI, Ángel Tomás A.

2001 Nuevas tierras con viejos ojos. Buenos Aires: Corregidor. 